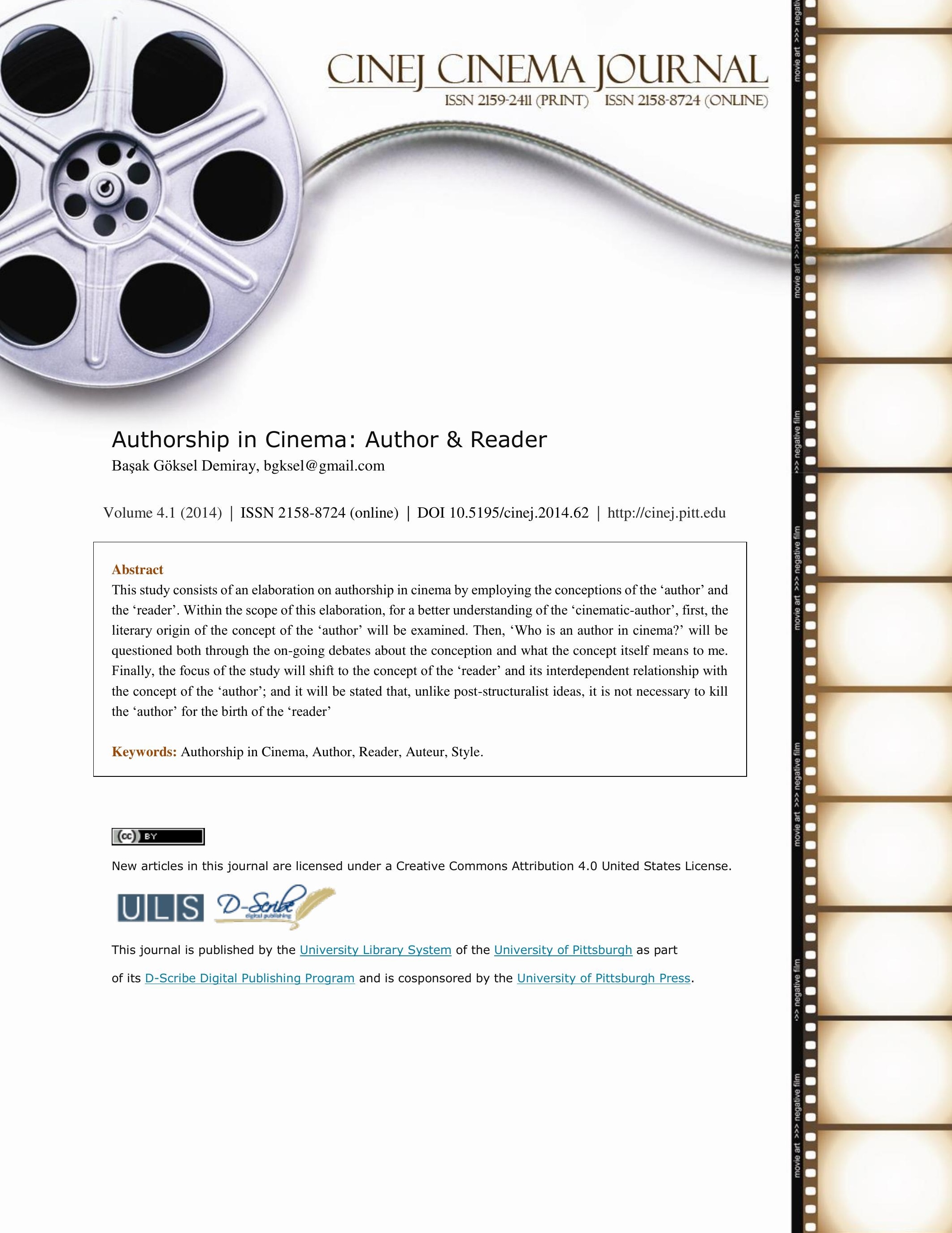




\title{
Authorship in Cinema: Author \& Reader
}

\author{
Başak Göksel Demiray
}

\section{AUTHORSHIP IN CINEMA: Author \& Reader}

Authorship has functioned on two basic levels in film studies: to argue for the artistic legitimacy of cinema, and to attribute the status of unique (God-like) artistry to the filmmaker who works in a collaborative process especially in Hollywood system. In this study, I will handle 'authorship in cinema' in the contexts of both the concepts of the 'author' and the 'reader'. For a better understanding of the answer to the question of 'Who is an author in cinema?', I will first elaborate the literary origin of the author. Then, I will examine the concept of the author in cinema, in the manner of the on-going debates about it and also what it means to me. Finally, I will focus on the concept of the reader with regard to the interdependent existences of the author and the reader in the context of cinema.

\section{The origin of the concept of the 'Author'}

Since literature is considered a high art from the elitist perspective of romantic tradition, cinema as the "seventh art" deployed literary concepts in its struggle to be accepted as a new art form. Writing, plot, narrative, genre, character are all now considered fundamental to the cinematic constitution. As Robert Stam points out, "cinema as the 'seventh art' implicitly granted film artists the same status as writers and painters." (Stam, 2000: 85) That is, the film artist is thought to make films in the same way the writer creates books. 
The 'writing' activity of the film artist occurs in two ways. The first is in the meaning of 'writing' the script of the film, while the second is a metaphorical meaning: 'writing on a pelicule' - i.e. recording the moving images on a negative film by means of a film camera. Orson Welles, one of the milestones of the abovementioned ways of 'writing' activity in cinema practice, defines 'film' in literary terms as "a band of celluloid like the blank sheet on which you write a poem. A film is what you write on the screen." (quoted in Cook, 2007: 402)

In fact, this tendency to explain the art of cinema through the use of literary terms can easily be seen initially in the naming endeavors of the medium. As Stam rightly stated, "many of the names for the cinema include some variant on 'graph' (Greek 'writing' or 'transcription') [i.e. biograph, animatographe, chronophotographe, scenarograph, cinematographe] and thus anticipate later tropes of filmic authorship and écriture ${ }^{1} . "($ Stam, 2000: 23)

Likewise, Alexandre Astruc, in his famous 1948 article "Birth of a New Avant-Garde: The Camera-Pen (La Camera-Stylo)", equates a film artist with a writer ${ }^{2}$ by conceiving of the camera as a pen with which to write "a worldview, a philosophy of life" (Cook, 2007: 390). Astruc's article, in its relationship with the activity of metaphorical 'writing', emphasizes the creativity of an individual artist and his unique style to record his personal vision of life on a pelicule.

In such a context, "La Camera-Stylo", as an acknowledged epoch-making article of auteurism, greatly implicates the concept of the "author / auteur". At this point, it should be

\footnotetext{
${ }^{1}$ Écriture, in French, means "writing". As Robert Stam emphasizes, "in the postwar period, film discourse, like literary discourse, became oriented around a constellation of concepts such as écriture, writing, and textuality. (Stam 2000: 86) This graphological trope dominated the period, from Astruc's 'camera-stylo' to Metz's later discussion of 'cinema and écriture' in Language and Cinema (1971)."

2 Dudley Andrew uses "novelist" instead. He defines the film artist who uses his camera to write as "letting his style be dictated by the exigencies of his material and his personal attitude toward that material." (Andrew 1976: 176)
} 
mentioned that even though it is the French form of a literary term 'author', auteur has a specific meaning in contemporary film studies, that of 'cinematic-author' who can be recognized through his handwriting or signature (style) available on the pelicule. Hence, in order to understand the concept of 'auteur', it is worth looking into the origin of the word 'author'.

Donovan, Fjellestad and Lunden claim that the origin of "author" is the Latin "auctor", which is derived from the verb augere, "to increase, augment, strengthen that which is already in existence $[\ldots]$ to exalt, embellish, enrich." (Donovan, Fjellestad and Lunden, 2008: 2) They emphasize that in Roman times "auctor" had multiple meanings: "cause, creator, author, inventor, producer, father, founder, teacher, and composer" (Donovan, Fjellestad and Lunden, 2008: 3). They also pointed out that the Greek word which corresponds to "author" is authentes - which comes from "autos + entes" and literally means "he who himself accomplishes, in other words, a doer, a master" (ibid).

Today, by its narrow definition, an "author" is the originator of a written work. Yet, in a broad/modern sense, having its roots in the eighteenth century's Romantic notion, the 'author' "is seen as both an exemplary human and somehow above or beyond the human, as literally and figuratively outstanding [...] after all, ahead of his time, avant-garde" (Bennett, 2005: 60). In the foregoing definition, Bennett emphasizes that the "author" is not only a human, but a consecrated entity, in the words of Donovan, Fjellestad and Lunden, a "Godlike figure". (Donovan, Fjellestad and Lunden, 2008: 7) The Oxford English Dictionary's definition includes a similar exaltation of the author:

an individual (singular) who is responsible for or who originates, who writes or composes a (literary) text and who is thereby considered as an inventor or founder and who is associated with the inventor or founder of all of nature, 
with God (with God-the-father), and is thought to have certain ownership rights over the text as well as a certain authority over its interpretation. (quoted in Bennett, 2005: 7)

If the author is a "Godlike figure", the emphasis should then also be put on his controlling mechanism over the entire creation process. He, as an autonomous individual, with his omnipotence, creates a unique/original work and knows what his work means.

Since the modern sense of the author developed in the Romantic era which Bakhtin defined by emphasizing the prevailing attitude as "the point [of Romantic sense] is not to surpass others in art, but to surpass art itself [which is to surpass artist at the same time]", the author is seen as much more than a flesh-and-blood artist. (quoted in Bennett, 2005: 56) In Bennett's words the author is "above or beyond" (i.e. surpassing) the artist (ibid). Indeed, from the Romantic point of view, numerous artists produced art-works in the history of art, but only the ones with a distinctive style were granted celebrity as "authors."

At this point it becomes clear that cinema struggled to be accepted as an art form, so as to get rid of the literary high art prejudice against its being mass culture production. To succeed in this struggle, cinema needed particular author-figures to elevate itself to the point of being considered a high art category like literature. Films have directors (i.e. film artists since the cinema is accepted as the seventh art) but only a few of them deserve to be considered an "author / auteur".

\section{Who is an 'Author' in Cinema?}

The initial debates on 'cinema' have started with the crucial questionings about its status as an 'art' or not. These questionings have stimulated another debate: the debate concerning the 
status of the filmmaker as an 'artist' or not. From the very beginning of the studies on cinema, it has been asserted that there should be a creative power, I mean an individual creator - implying an 'artistry' but naming it variously - like photoplay master, filmmaker, filmwright, director, author, author-director, camera-pen, cinematic author or auteur on the basis of the filmmaking activity. In 1915, Vachel Lindsay in his book The Art of the Moving Picture predicts auteurism that "We will some day distinguish the different photoplay masters as we now delight in the separate tang of O. Henry and Mark Twain." (Stam, 2000: 32,33) The first employment of the term 'author' to call for the filmmaker has emerged in Jean Epstein's Le Cinema et les lettres modernes, 1925. (Stam, 2000: 33) In the meantime, Louis Delluc was analyzing the films of Griffith, Chaplin, Ince and Tourneur. Stephen Crofts claims that Delluc's those analyses foreshadowed auteurism in the style of the Cahiers du Cinema of the 1950s. (Crofts, 1998: 312)

The 'author'- the term that was used for the first time in its French form auteur as a critical issue in film culture, in François Truffaut's A Certain Tendency of the French Cinema - is the one who is the 'authority' ${ }^{3}$ in all the processes of making a particular film. He is the decision maker, he is a choice maker from pre-production to the screening of the film on theatres. In general he is the scriptwriter of his own films. Sometimes he is also the producer, the director of photography, the art director, the musician, the editor or the actress/actor of his own films.

The difference between the 'director' and the 'author' reveals itself in investigating the consistency, meaning, persistence of style and theme in the corpus of his films. Quests for the concept of 'author' are still going on for decades "to distinguish authors from the anonymous mass of directors, to establish their identity by reference to their most characteristic work and

\footnotetext{
3 The relationship between the words 'author' and 'authority' will be emphasized throughout the text to be more clear in answering the title question.
} 
distinguishing style or thematic focus, and to pass judgment as to their respective merits". (Lapsey and Westlake, 1988: 127) As Lapsey and Westlake suppose, there are authors on one side and there are the "anonymous mass of directors" on the other. Every film has a director but every director is not the 'authority' of the film he directs. Because a film must be the bearer of its director's signature. The individual style, the world view, the spiritual insight, the proficiency of his own craft and the other artistic talents (such as music, poetry, painting, writing) are some of the personal characteristics which determine the director's choices and decisions. Every director makes decisions and choices. However we can not talk about any 'authority' existing in a corpus of any given director's films when there is no coherence and persistence, when the director is rarely distinguishable from the mass of other functionaries, and when the film seems as an anonymous work without name and without signature. A signature ${ }^{4}$ is a signifier of an 'authority' and the 'author'.

${ }^{4}$ A 'signature' is a kind of guarantee that provides a confidence between personal or institutional sides. One guarantees that if he signs a paper, his signature will mean that he has the ability to do what he promised. 'Signing' something easily without any concern or doubt shows that the person who signs a paper can easily manage to take responsibility of what he promised to do. If a person is not self-confident in any case of life, he cannot sign any paper. If he signs although his lack of ability to manage whatever he promises then he fails. Thus, anyone who is not selfconfident, who can not take responsibilities and achieve in life, can never be an 'authority' in any field of life. On the contrary, a person who is consistent, responsible, reliable, generally successful in a particular field or fields may have a chance to be an 'authority' or may not. For instance, in a bank many managers may have the qualifications that I have mentioned previously but the only one among them deserves to be a general manager. What distinguishes him from the others is metaphorically his signature again. Signature is a drawing which reflects the style, the character and the personality traits of someone. A general manager in a bank must have a distinctive style, talents, traits, abilities to reach that rank instead of the other managers and to be an 'authority' over them. Then his signature can be the only one that is accepted as valid on the most important, valuable, strategic contracts of the institution (bank). The assignment I have made at the beginning of my elaboration that "a signature is a signifier of an 'authority' and the 'author' ", sums how authors are distinguished from the anonymous mass of directors. They are/have the 'authority' on every moment of making their films, they have individual styles, and unique signatures. 
In the article "Style and Personality in the Literary Work", Jenefer M. Robinson supposes how to stay away from the 'anonymity'. She sums up what I have discussed since the beginning, but in the context of literature. She puts styles in two categories: general style and individual style.

If a work belongs to a general style category, then, although it may have formal and expressive qualities that are distinctive of that style, it may nevertheless remain "characterless": no personality "informs" the work. Alternatively, there may be personality traits expressed but they do not seem to belong to any particular individual. The work has an "anonymous" air about it, because the artistic acts are performed in a way which is common to a large number of different writers [...] the defining quality of an individual style is that it expresses a coherent set of attitudes, qualities of mind and so on which seem to belong the individual writer of the work: a work which has an individual style expresses the personality of the implied author of that work. (Robinson, 2004: 419)

Up to now I have focused on the necessity of the individuality to name a director as an auteur. However, there are also social, political, ideological, technical, and economical determinants that effect the choices and the decisions of the auteur as well as his individuality does. At this point, an 'auteur' as an 'authority' and as the 'unique creator' of his film confronts many debates. James Naremore accepts that "authors are 'written' by a series of historical, social and cultural determinants" and emphasizes that the concept of the 'author' is needed to be understood dialectically with an awareness of the complicated, dynamic relationship between institutions, artists and particular circumstances. (Naremore, 2005:22) Naremore gives attention to the choices of authors (auteurs), even they are made in some particular conditions. Lapsey and Westlake give another example of the ability to protect authorial function and the 'authority' under various conditions, by reminding that the 'auteurists' invoked some artists like Mozart and 
Michaelangelo, whose work had also been subject to institutional constraints, and also pointed out that there were undeniable directors within Hollywood whose films displayed a discernible consistency and identity of style. (Lapsey and Westlake, 1988: 107) Peter Wollen supposes that Howard Hawks is that kind of a director. In his study "The Auteur Theory", he emphasizes that "Howard Hawks is a director who has worked for years within the Hollywood system. He has worked in almost every genre. Yet all of his films exhibit the same thematic preoccupations, the same recurring motifs and incidents, the same visual style and tempo." (Wollen, 2000: 73) Although Hawks had been worked in the studio system and forced to direct many films in different genres under the authority of the studios, he achieved to impose his own style to the films by means of his authority.

On the contrary of the instances that I mentioned above, Lapsey and Westlake also point out that "historical materialism ${ }^{5}$ directed attention to two constellations of production: the film as a commodity with various determinants; and the production by the film of meanings with ideological and political effectiveness. [...] these both entailed rethinking the notion of the author". Lapsey and Westlake continue to explain in the context of historical materialism that author is no more seen in the romantic notion of an artist and also his films are seen as the effects of a whole array of determinations making up any particular conjuncture. (Lapsey and Westlake, 1988: 112) Instead of denying the entity of the author (auteur) as the historical materialists did, "more

\footnotetext{
5 "Historical materialism is a methodological approach to the study of society, economics, and history, first articulated by Karl Marx (1818-1883). Marx himself never used the term but referred to his approach as 'the materialist conception of history. 'Historical materialism looks for the causes of developments and changes in human society in the means by which humans collectively produce the necessities of life. The non-economic features of a society (e.g. social classes, political structures, ideologies) are seen as being an outgrowth of its economic activity." (Wikipedia)
} 
promising was the approach suggested by the Althusserian notion of 'relative autonomy', which would allow both the specificity of a distinctive authorial signifying practice and that of the social formation to be respected.”(Lapsey and Westlake, 1988: 115)

In fact there are various determinants which effect or restrict the individuality of authors. However an author is an artist who confronts and adapts the external effects/determinations/constraints to his own work by his own style or who is being partially adapted to them by not giving up to protect his own autonomy in its acceptable limitations. What I am trying to define by using the word 'adapt' is mentioned by Colin MacCabe as "individual as autonomous and whole, liable only to contingent constraints." (Lapsey and Westlake, 1988: 113) The autonomy of an artist even it is relative or not, can be kept protected in any circumstance only by artist's own self. The artist can never be totally imprisoned by rules, by ideologies, by genres because creativity occurs in human minds and nobody can control it. An author may be seen surrendering the conditions and sometimes depending on them but he always inscribes something individual to his all works. The recognizable consistency and persistence of his style under any condition make him the 'authority' of his oeuvre.

In conclusion, I will ask a question that leads me to write the next part. On the contrary of personal arts such as painting or literature, cinema is a team-art. However, I have defined the author as an individual who is the unique authority in the filmmaking process, controlling all departments

\footnotetext{
${ }^{6}$ Michael Rosenthal explains the relative autonomy as: "Engels wrote numerous letters after the death of Marx protesting, with increasing urgency, the economic reductionism taking hold in the Marxist movement. Recently, French Communist Party theorist Louis Althusser has attempted an important reformulation of the terms of the problem. Drawing from Engel's letters, Althusser argues that the various superstructures (law, politics, ideology) are characterized by a "relative autonomy" from the base. These structures take concrete form in material apparatuses (such as the judicial apparatus or the state apparatus), which have their own specific unity and coherence. Each plays a part in determining social events, although the economic structures remain "determinant in the last instance"." (Rosenthal, 1978: 19-22)
}

CINEJ Cinema Journal: Authorship in Cinema: Author \& Reader 
of the production, and leading them by his choices and decisions. What if there is no author (director) in a film? Will it have a style? Whose style will dominate the film: director of photographer's, art director's, scriptwriter's, actor's, editor's, producer's or the spectator's?

\section{A 'Reader' in Cinema}

If a film has no author, it has inevitably an eclectic style or Jenefer M. Robinson's 'general style'. An author constructs the unique style in the film by his unifying ability which is bound to his own authority. The necessity of the author's 'authority' started to be reduced notably by the attempt to unite auteurism and structuralism. The most significant work on auteur-structuralism is Peter Wollen's Signs and Meaning in The Cinema $(1969,1972)$. For Wollen, auteur-structuralism was a scientific approach based on the structuralism of Levi-Strauss. Lapsey and Westlake suggests this scientific approach as "a first step towards distinguishing the empirical author from the author constructed by (because desired by) the reader." (Lapsey and Westlake, 1988: 111) Similarly, Stephen Crofts defines the author in the context of auteur-structuralism that "the author, as set of structures is identifiable by the reader within a director's films." (Crofts, 1998: 315)

For the structural analysis, in the manner of Levi-Strauss, there should be an author and a text. However there is a tendency to discount the former from consideration. Lapsey and Westlake explain this tendency by emphasizing the importance that is given to 'objective structure': "Instead of the personal vision of the creative artist the new methodology would reveal in any given oeuvre an objective structure that generated its characteristic meanings, patterns and intensities." (Lapsey and Westlake, 1988: 109) How can an objective structure be revealed in any given oeuvre? Peter Wollen, in the manner of Levi-Strauss, supposed to use 'master antinomy' (binary oppositions) as 
a method to reveal it. He explains that, by using 'master antinomy' texts can be studied not only in their universality (resemblances) but also in their singularity (differences).” (Wollen, 2000: 74) However, his approach stays away from the auteur- specificity. Particularly, his studies on John Ford have stimulated many controversies. One specific criticism about them is "It is not clear how distinctive and specific a structure has to be before it becomes author-specific; the oppositions that Wollen identifies in John Ford's work are virtually indistinguishable from those used by other critics to define the Western genre." (Hollows, Hutchings and Jancovich, 2000: 50)

In addition to the doubts about the adequacy of the 'binary oppositions' to analyze the structure of the text, Wollen is subjected to some other criticisms because of his acknowledgement of the author (auteur) as an 'unconscious catalyst' since his work Signs and Meaning in The Cinema $(1969,1972)$ was based on the system of 'the unconscious'. Levi-Strauss said "not only language but all human culture is governed by a system of mental constraints operating according to binary oppositional features, a system he termed 'the unconscious"' (Lapsey and Westlake, 1988: 108) In the first edition of his book "it was the structuring activity of the director, conscious or unconscious, that generated the distinctive character of the work. In the second edition, it is emphasized that 'unconscious, unintended meaning [that] can be decoded in the film, even surprising the individual involved'." (Lapsey and Westlake, 1988: 111) Wollen claims in the conclusion of 1972 edition that "the author be an unconscious catalyst [...] because it is through the force of the author's own preoccupations that an unconscious, unintended meaning can be decoded in the film" (quoted in Crofts, 1998: 316). It is ambivalent in Peter Wollen's discourse that why an author (auteur) is an unconscious catalyst? Because of the mental system that LeviStrauss emphasized? or Because of the preoccupations of the auteur's own? Through all the debates about Wollen's work, Lapsey and Westlake sums that "the 1972 edition may be read more 
productively not as a resolution of the problem of synthesing auteurism and structuralism, but as a transitional text from a pre-structuralist concept of the author as creator of meaning to a poststructuralist one, 'author' as a construct of the reader.”(Lapsey and Westlake, 1988: 111)

The tendency on weakening the power and the authority of the empirical author - starting in the attempt named 'auteur-structuralism' - is enunciated more stridently by the post-structuralist ideas, most notably by Roland Barthes and Michel Foucault. In the agency of post-structuralism,

Theory replaced the study of the author with the study of the sign systems through which ideology was represented. The author became a kind of epiphenomenon - an ideological or historical construction. Two French essays strongly influenced this tendency: in "What is an Author?" Michel Foucault deconstructed the authorial "function," showing its relationship to early Christian exegesis, to the rationalist episteme of bourgeois society, and to legal or property rights; and in "From Work to Text," Roland Barthes contrasted the authorized work of art - which, he argued, was little more than a reified commodity - with the open-ended process of textuality, which seemed to belong to the reader, or to nobody in particular. (quoted in Naremore, 2005: 19)

When the author became a kind of epiphenomenon, then the reader became the sole point of reference. Barthes manifestation “ 'the death of the author' is 'the birth of the reader' " (Lapsey and Westlake, 1988: 125) aims to explain that "meaning can no longer be thought of as originating in the mind of author, and emerges only in the act of reading." (Lapsey and Westlake, 1988: 124) According to him, "the reader is the space on which all the quotations that make up a writing are inscribed without any of them being lost; a text's unity lies not in its origin but in its destination." (Lapsey and Westlake, 1988: 124) Barthes defined the reader as the destination of the text and he is not interested in the starting (i.e. originating) point of it. "Like Barthes, Foucault accepted that the author as God was dead, this being the concomitant of the philosophical move away from 'the 
theme of an originating subject."' (Lapsey and Westlake, 1988: 125). At this point Jacques Derrida explains the term 'destination' in the message-sender relation: "In all forms of signification the intentions of the sender (author) of a message might not be realized, a letter might not reach its destination. An author can no more determine how his or her text is read than can the sender of a message control its reception." (Lapsey and Westlake, 1988: 124, 125)

To sum up all the theoretical quotations that I have mentioned above, I will focus on "the birth of the reader'. Is it necessary to kill the author to give a birth to the reader? I don't think so. Since the cinema is an art form constructed on the base of exhibition in public places to the mass of spectators, its first aim is to reach its audience. The author makes his films to share his vision and style, to tell his story. It means nothing if anybody reads it. Cinema is not an art form for an author to produce a film and watch it alone at home without showing anybody. Thus, the reader is as important as the author in this process and the meaning that the reader perceives from the text is important as well as the meaning created by the author. It is not necessary that both these meanings, which have different origins, must be the same. They may or they may not because they are produced by different minds. Sometimes the reader analyse totally different meanings in the films that the author is not aware. Sometimes a letter might not reach its destination as Derrida says. Sometimes the author constructs his texts on some particular structures but they may function totally different in the reader's minds. Since both sides have different styles, world views, thoughts, ideologies, talents, senses, beliefs and since they both live in different social, political, economic, traditional conditions, it may not be possible to attribute fixed meanings to the work of art from the two different perspectives. However, without killing the author and his authority, a reader must take the text as a criterion. He must study on the meanings that he perceived from the films of a given author. He must not ignore the empirical author and the elements, which 
distinguish that author from the others, but on the other hand he must not bound to them blindly.

However, if a reader does not stay away from the self-image of the author, he cannot catch a distinctive approach.

In conclusion, throughout this work, it was shown that "authorship in cinema" is conceptualized with an emphasis on 'style'. From the very beginning, the concept of the 'author/auteur' had an emphasis on 'individual style' established through the ability of a director to write on a pelicule; auteurism, in this sense, cared not much for 'what' is written, but 'how' it is written. At this point, the 'reader' is the one that is able to reveal the unique 'style' of an author - perhaps with a need to idealize or glorify him or the tendency to identify with him by means of proving the possible 'coherence' in his body of works that his 'style' provides.

\section{BIBLIOGRAPHY}

Andrew, D., 1976. The major film theories: An introduction. New York: Oxford University Press. Bennett, A., 2005. The author: The new critical idiom. London: Routledge.

Cook, P., 2007. The cinema book. London: BFI.

Crofts, Stephen. 1998. "Authorship and Hollywood” in The Oxford Guide To Film Studies, Hill J. and Church Gibson P. (Ed.). Oxford University Press, pp. 310-326.

Donovan, S., Zadworna-Fjellestad, D. and Lundén, R., 2008. "Introduction: Author, authorship, authority, and other matters" in Authority matters: Rethinking the theory and practice of authorship. Donovan, S., Zadworna-Fjellestad, D. and Lundén, R. (Ed.). Amsterdam/New york: Rodopi, pp. 1-23.

Hollows, Joanne and Peter Hutchings, Mark Jancovich. 2000. "Film and Authorship" in The Film Studies Reader. Hollows J., Hutchings P. and Jancovich M. (Ed.). Arnold Publishers, pp. 45-81.

Lapsey, Robert and Michael Westlake. 1988. "Authorship" in Film Theory: An Introduction. Manchester/UK: Manchester University Press, pp. 105-128.

Naremore, James. 2005. "Authorship" in A Companion to Film Theory. edited by Miller T. and Stam R (Ed.). Blackwell Publishing, pp. 9-24. 
Robinson, Jenefer M..2004. "Style and Personality in the Literary Work" in Aesthetics and the Philosophy of Art: The Analytic Tradition: An Anthology. Lamarque P. and Haugom Olsen S. (Ed.). Blackwell Publishing, pp. 411-422.

Rosenthal, Michael. 1978/2005. "Ideology, Determinism and Relative Autonomy" at http://www.ejumpcut.org/archive/onlinessays/JC17folder/RelativeAutonomy.html

http://en.wikipedia.org/wiki/Historical_materialism _

Stam, Robert. 2000. Film Theory: An Introduction. Blackwell Publishing.

Wollen, Peter. 2000. “The Auteur Theory” in The Film Studies Reader. Hollows J., Hutchings P. and Jancovich M. (Ed.). Arnold Publishers, pp. 71-78. 